\title{
Un-gendering the ocean: why women matter in ocean governance for sustainability
}

\begin{abstract}
This viewpoint emphasizes gendered perspectives and reflects on gender roles for sustainabilityfocused governance. It argues that when considering gender in this context, not only equity, or power-plays between genders are at stake; for effective ocean governance, an irreducible contribution of female voices is necessary. Some key contributions of women in the field of ocean governance-related research are described as examples. If women, for instance, are not included in fisheries management, we miss the complete picture of social-ecological linkages of marine ecosystems. Overall, women are often regarded as major actors driving sustainable development because of their inclusiveness and collaborative roles. Similarly, women have advocated for the common good in marine conservation, raising important (and often neglected) concerns. In maritime industries, women enlarge the talent pool for innovation and smart growth. Besides the manifold possibilities for promoting the involvement of women in ocean governance and policymaking, this viewpoint highlights how gendered biases still influence our interactions with the ocean. It is necessary to reduce the structural, and systemically-embedded hurdles that continue to lead to gendered decision-taking with regard to the ocean.
\end{abstract}

This is the accepted manuscript of a paper originally published in Marine Policy. You may find the final, formatted version at $\underline{10.1016 / \mathrm{j} . \mathrm{marpol.2018.05.020}}$.

Keywords: ocean governance; sustainable development goals; environmental conservation; fishery management; maritime industry; natural resources; inclusiveness; decision-making; gendered perspective

\section{Highlights}

1. The viewpoint reflects on women's contribution to a sustainable ocean governance

2. Gendered biases still influence our interaction with the ocean

3. Some key contributions of women in ocean governance-related research are described

4. Examples on fishery, ocean conservation, sustainability, maritime industry included

5. Ocean governance needs acknowledging women's role for its effectiveness 


\section{Introduction}

In the human realm, just as in the animal world, the sea is a suitable backdrop for the unwinding of the dramas played out between different genders. ${ }^{1}$ Among its direct inhabitants are fascinating exemplars such as the mesmerizing clownfish (Amphiprion percula) and the unsightly parasitic anglerfish (Neoceratias spinifer), the former a sequential hermaphrodite while the latter exhibits extreme sexual dimorphism [1]. Clownfish thrive in groups, all males until the largest, most dominant "family" member morphs into a female who then mates incestuously with a series of males until replaced by the next dominant male-turned-matriarch. Male anglerfish live out their entire lives as tiny, helpless and blind parasitic dwarves attached to the larger female, surviving only while infused through most of their organs, including their circulatory system, to the female host.

But what of humans? How do human-beings relate to the seas and how does our gender as a social, rather than merely a biological attribute, influence our relationship to the marine environment and to each other?

These are questions that require more research, and yet, they suggest that there is lack of knowledge about gender relations vis á vis ocean governance and research [2]. In the early days of internationally coordinated governance discussions, with activist Elizabeth Mann Borgese already the ocean had a crucial female representative [3]. The United Nations Convention on the Law of the Sea (UNCLOS) was actively co-shaped by the Pacem in Maribus (Peace in the Ocean) discussions initiated by Borgese. During this period (late 1960s to early 1980s), with her crucial contribution, many important installments to the international ocean governance framework were made. Yet, these contributions were made to the general field of ocean governance, not necessarily related to a gendered or diversity-oriented perspective to ocean governance and marine research and how these come together to promote sustainability.

This viewpoint highlights gendered perspectives as they relate to the promotion of the Sustainable Development Agenda of the United Nations [4]. As such, it reflects on the role and potential contribution that gender has to sustainability focused ocean governance. Governance is defined as the political, social, economic, and administrative systems and related formal and informal

\footnotetext{
${ }^{1}$ In 2008-2009, Isabella Rossellini launched the "Green Porno" series on the Sundance Channel. The focus on the variety of mating in living organisms was to raise awareness on conservation and unconventional plays between genders. The third and final season of Green Porno puts a focus on conservation of ocean life with featured biologist Claudio Campagna providing insights into the depletion of ocean resources; source: http://www.sundance.tv/series/greenporno (accessed at 13/10/17).
} 
institutional arrangements involved in the management of natural resources [5,6]. For effective sustainability-focused ocean governance (i.e., a governance regime achieving its sustainabilityoriented objectives, as social inclusion among the others [7]) women are needed for moral and ethical reasons (see Jaggar, "Feminist Ethics" [8]), mostly because of the need to eliminate barriers to the participation of women in public decisions about the oceans. Therefore, what is at stake is not only equity, or power-play between genders - as is often argued in the field of gender studies (see [9]) - but the effective achievement of sustainability through ocean governance. This viewpoint proposes addressing these issues through the lens of the multiple, and often overlooked contributions of women, and thus encourages strong involvement of females in the field and especially those with varied socio-cultural backgrounds.

The important role that women may bring to ocean governance efforts can be highlighted by reviewing some of their contributions from within a range of social, cultural and historical contexts. By discussing and exemplifying some contributions of selected female colleagues in balancing development and marine conservation through research, this paper reiterates important contributions women make to the field of ocean governance in an era of increasing threats to the global oceans.

\section{Women and the ocean - A chronological perspective by category}

While twentieth-century science was dominated by men, resulting in a male bias in research questions and findings [10], the recently published Global Ocean Science Report by IOC-UNESCO assesses that with a $38 \%$ share of female ocean researchers globally, gender diversity in ocean-related research is $10 \%$ higher than in research overall [11]. The following, in form of a non-exhaustive overview, traces some of the contributions offered by a number of women to marine resources governance. By doing so, the aim is to reflect on the role of greater gender diversity in marine resources related to research and policy-making. ${ }^{2}$

\subsection{Traditional fisherfolk societies}

Marine-related fields have been uniquely affected by gender biases over the years. Whether in the context of industrial and small-scale fisheries, or aboard ships and vessels, the gendered life worlds

\footnotetext{
${ }^{2}$ A search of the on-line data bases ISI Web of Knowledge and Scopus using the key words

"marine/ocean/sea/coastal/maritime", "gender/woman/women" and "time preferences/sustainability/SDGs/natural resource/Common pool resources" identified 212 articles (at 10/08/2017).
} 
of marine-based societies, have been amply documented, particularly in terms of how sailing, surfing, maritime navigation, and other forms of seafaring have historically been perceived as distinctly "masculinized" practices $[12,13]$. Yet these (interpretative) gendered essentialisms have also been critiqued across anthropological and transcultural scholarship spanning Oceania and the Mekong borderlands to Madagascar (cf. [14-16]), which in turn illustrate the (internally diverse) livelihood practices and ontologies of distinct sub-groups such as female pearl divers or Indigenous fisherwomen. According to one of the world's experts on fisheries science, Daniel Pauly [17], the world is a "much divided" one to begin with, and gender, among other divisions, is particularly acute in fisheries science because it is so cultural, site-specific and historically-bound.

Traditionally women have had a significant role in fishing (artisanal, commercial) and in the fisherfolk societies [17], yet one that is often overlooked or downplayed [18]. In a study that summarizes existing knowledges on women's participation in marine fisheries globally, Harper et al. [19] found that women play important roles in the entire fishery supply chain world-wide. However, despite fisheries being a recognized activity heavily participated in by women, the authors of the study contend that fisheries statistics often fail to capture this contribution. As analyzed by Kleiber et al. [20] for the case of small-scale fisheries, excluding gender analyses leads to the underestimation of the human catch and the diversity of species and habitats targeted by fishers, hampering a broader social-ecological understanding of fisheries.

Recently, gender-specific female roles in fisheries have been consciously assessed for their potential contribution to sustainable practices. Economic experiments conducted among fishermen from the Mexican and Colombian Pacific found that women presented more sustainable catches than men [21]. Similarly, Fonseca et al. [22] found that women in charge of small-scale artisanal fisheries in Brazil, significantly assured that these geographically and quantitatively limited resource management and use systems met high standards of sustainability. Kim [23] observes a similar distinction regarding gender-specific practices in predominantly female small-scale farmers in rural Uzbekistan when compared to the agricultural practices of the predominantly male largescale farmers in the same region.

Yet, how much do gender-specific differences continue to play a significant role with regard to ocean governance? Zhao et al. [24] have shown that men and women's role were re-negotiated under the impacts of policy changes of catch quota in Northern England, with women also getting more politically involved, leading eventually to "(...) a greater part in decision-making in families, communities and beyond” (p. 73). In a study of Oregon's coastal fishing communities, Calhoun et al. [20] argue that female roles in fishery are likely to continue to change because of the diverse 
response of individuals (among them many women) to regulatory, market- and management-driven changes. Indeed, place-based approaches are needed to understand the diversity of impacts of catch share policies because individuals (men and women) and communities are affected differently under the impulse of a variety of fishery management programs [25]. From these examples, the predominance of gender-specific role patterns seems unlikely to continue to hold, but rather that evolving and diverse responses are being continuously created.

\subsection{Women and marine conservation}

Besides Elizabeth Mann Borgese (mentioned above) there have been several outstanding female activist scientists that have been pivotal in the field of marine conservation. Of special note is of course Rachel Carson. As an aquatic biologist, author-activist and considered by many to be the first modern-day environmentalist, Carson began her writing career documenting the sea and appealing to the general public about environmental health, first and foremost through a concern for marine conservation. Before becoming a champion in the fight for controls of toxic chemicals, including pesticides such as DDT, she published three best-sellers: Under the Sea Wind (1941), The Sea Around Us (1951) and The Edge of the Sea (1955). In 1957 Carson wrote: “...the shore can never again be itself once man has 'developed' it. The dismal truth is that shores... are fast disappearing, and may well do so completely within the life of some of us." [26]. She was a caregiver par excellence, as she dedicated herself to the well-being of future generations, contributing substantially by putting the human-environment relationship on the political agenda [27]. Although there is no evidence that Rachel Carson defined herself a "feminist", at the time that she started opposing the military, capitalism, the collusion of scientist and industry and more, no one made ostensibly "feminist" claims [27]. In any case, her perspectives undoubtedly emphasized marine conservation.

Another well-known female marine conservationist is of course Sylvia Earle. Dubbed "Her Deepness" by The New Yorker in 1998, Earle has been explorer in residence of National Geographic and has worked for most of her career to advance marine conservation. Despite her professional achievements as a scientific diver she was kept from joining an all-male aquanaut team in the 1960s [28]; her subsequent leading of an all-female team of aquanauts brought her national attention and in many respects international stardom. In recent years, her high profile has aided her in rallying support for Mission Blue, (a.k.a the Sylvia Earle Alliance), a non-profit foundation dedicated to the establishment of worldwide networks of marine protected areas. 
Although we point only to two examples, women have made unique and distinctive contributions to the study of oceanography and to knowledge of Earth and its ocean [29]. For instance, within the broad realm of marine conservation, it is worthy to point out women's prevalence in the study of marine litter. Though seemingly naturalistic and stereotyped, women's role in this field may have to have something to do with the accepted role of women as "cleaners" and caretakers, as in traditional societies [30]. Gender scholarship posits that differences can be mapped based on how people, influenced by gender-specific role patterns and profiling in society, perceive, experience and respond to environmental problems differently and therefore may be worth applying to the field of ocean governance and/or specifically to marine conservation as advanced by ocean governance.

With regard to plays between genders, it is indeed worth noting that gender scholarship is constantly evolving, increasingly spanning the whole spectrum of multiple sexes and sexualities beyond the male/female simplification. In an edited book on gender and the environment, Sherilyn MacGregor [9] describes the narrative of "women saving the planet" as simplistic. She also reminds us that the relation between "gender" and the "environment" has been molded differently in the last 50 years that it had been in the more distant past, with activist goals shaping how these terms are conceived and studied. These views further support the need to broaden the connections between gender studies and the environment such that ocean governance and marine protection are considered, researched and reviewed.

It has already been stated publicly that environmental conservation benefits from enlarging the contribution of women and their insights beyond women-specific role enactment in natural resource management. In 2014, in an effort of blurring boundaries between intrinsic and instrumental values of nature, Heather Tallis and Jane Lubchenco [31] launched (through Nature) a petition signed by 238 leading world scientists - men and women - "for an end to the infighting that is stalling progress in protecting the planet" (p. 27). They observed that "gender and cultural bias also continue to hinder conservation" (p. 28). They advocated a conservation ethic that is diverse in its acceptance of genders, cultures, ages and values [31], embracing all plausible conservation actors, including women, for advancing and sharing knowledge in all relevant disciplines and contexts for effective actions.

\subsection{Women in sustainable development}

The current UN Sustainable Development Goals (SDGs) single-out poverty eradication in all forms as the greatest challenge and as an indispensable requirement for sustainable development [32] and 
identify it as one that relates to all 17 SDGs. Women can play an important role under the general task of eradicating poverty; special opportunities to include them should be advanced. Women are recognized for their role in household income, food security, and marine conservation $[9,18,19$, $33,34]$. Women have been found, due to the social role patterns performed, to show greater aptitude in changing their behavior towards lower resource extraction compared to men, when regulations, sanctions or social scolding were introduced [35]. Women were also recognized as key agents in the adoption of ethical principles that can initiate change in individual behavior, attitude and actions towards sustainability in fisheries [36]. Madrigal-Ballestreto et al. [33] found that women are more likely to follow the rules for conservation activities in community-based projects, because of the multiple benefits of self-esteem, empowerment and self-determination. Taken together, these insights suggest that raising the role of women in decision-making, along with supports from adequate institutional frameworks, may facilitate sustainable approaches, due to being reflected from a wider range of experiences relevant to the use of natural resources.

With regard to development goals, it is important to note that in natural resource management and climate change issues gender is more frequently recognized as a category of analysis in developing countries than in the industrialized West $[9,37,38]$. Examples of women working to support community-level sustainable development processes can be found in research conducted in Africa [39-41], Asia [42, 43], the Pacific Islands [34, 36] and Central America [44]. By contrast, in Sweden - as an example of the industrialized West - Westberg and Powell [38] discovered that competences related to holistic and learning-oriented approaches required by policy documents and directives within environmental management agencies are, in addition to being gendered, also under-valued because they are gendered. They argue that "the feminization of participatory environmental management leads to these approaches having less status and less influential power than do the traditional, masculine approaches in bureaucratic organizations" (p. 14). Baker-Médard [41] suggest going beyond the rhetoric of "community involvement" to address gendered inequalities in resource management decision-making, reinforcing the point that gender-equitable approaches are crucial to sustainable development of ocean resources [2]. Existing practices can help in overcoming such a gendered divide between developing countries and the industrialized West. For example, the gender social-ecological analysis of coastal communities as presented in de la Torre-Castro et al. [40] represents a viable generic tool to support sustainable development in settings beyond those in Africa.

\subsection{Women in (non-fishing related) maritime industry}


In the past, the maritime industry has been largely male-dominated [45, 46]. As a case in point, a study on women as seafarers of the International Labour [47] found out that women were only 1-2\% of the world's 1.25 million seafarers, with the higher workforce percentage of $17-18 \%$ in the cruise line sector. While some have credited this difference with the gendered perception of women's work $[48]^{3}$, in order to counteract evidence of male domination of the industry, from 1989 the International Maritime Organization (IMO) has supported a capacity building program "MDG 3: Strengthening Maritime Resource Development" [49]. This program, initially called "Strategy on the Integration of Women in the Maritime Sector" (IWMS), encourages the participation of women in all spheres of the maritime sector. With the second conference on "Maritime Women: Global Leadership" held in 2014 by the World Maritime University (WMU) in Sweden, "gender-related issues" were observed among various maritime sectors, including seafaring, ports, administration, law and education [45]. Kitada et al. [45] posited that women's unique contribution served the concept of a sustainable maritime transportation system declared by IMO in 2013 [50]. No doubt, including women as part of a diverse maritime workforce enlarges the "talent pool" available for highly competitive market [51], providing a global benefit for public and private maritime sectors. Impediments and opportunities for women in marine activities exist, including in science. Among impediments have been the concern for a limited number of women aboard ships during voyages and concerns for their safety [52]. The ILO [47] states that efforts need to be made to create a more "normal" social environment onboard ship. An opportunity is available for woman to take on leadership roles even in creating such "social environments". The IMO [53] seeks to encourage the equal participation of women in all areas of maritime training and research.

The recognition of impediments has resulted in emphasis on networking and mentoring as an effective strategy for the integration of women in the maritime sector, as well as to increase leadership capacity in trade unions and in science. The Women's International Shipping and Trading Association (WISTA), through its core values (professional, dynamic, committed, openminded, source: http://www.wista.net/en/site/home), targets innovation, technological advancements and sustainability for the sake of maritime industry as primary objective, built through the proactive dialogue of genders.

\footnotetext{
${ }^{3}$ as women "are born to perform domestic work based on an inherent ability to care, to nurture, to pay attention to detail, and to entertain passengers" [44]. Moreover, "women seafarers' positions in cruise sector is demarcated by a hierarchized nexus of region/nationality and race/ethnicity, i.e. Western European, followed by Latin American, Easter European and Asian women" [44].
} 


\section{Why women matter}

As shown here, historically women have played an important role in advancing a number of issues central to ocean governance as understood today. Gender contribution in fishery management is far more advanced and acknowledged than in the other maritime sectors, because of the input given to gender research.

This paper has described examples of some of women's contribution in maritime sectors including in fisheries and in marine conservation. In the maritime industry, as pointed out above and even in the Blue Economy literature [2], many socio-political elements related to power, agency and even gender, are all areas needed for sustainable ocean governance to be achieved. Sustainable fisheries, marine conservation and the sustainable development of the blue economy are at the very core of the SDG 14 which aims to "....conserve and sustainably use the oceans, seas and marine resources".

"Blurring boundaries" refers to removing the cultural barriers of a male-dominated world for women to access governance of the oceans for the sake of achieving sustainability. The marine environment and those dependent on it, have much to gain from "blurring" lines or boundaries with regard to who has a mandate to govern ocean space and who has a say about the allocation of its resources. In the past, it seems that the above-mentioned male dominance in science also may have contributed to the "carving up of the ocean space" and the allocation of its resources in pre-existent power networks. The SDGs discussions consciously aim for the involvement of, amongst other aspects, gender-wise diverse voices for building a globally united ownership of sustainable development and mobilize diverse action towards it accordingly.

This viewpoint has reflected on the role of women in and for ocean governance. We have highlighted some of the key contributions of women in the field of ocean governance related research. We could go on mentioning - in alphabetical order - Tundi Agardy, Rita Astuti, Ratana Chuenpagdee, Biliana Cicin-Sain, Louise Glew, Jane Lubchenco, Bonnie McCay Merrit, Evelyn Pinkerton, and Meryl J. Williams, but the list would still look very incomplete. Some examples that we found sporadically and episodically in the literature, and reported on here, suggest that further systematic investigation is needed. Moreover, gender biases still significantly influence humans' interaction with the ocean. By not including women in fishery management, we miss the complete picture of social-ecological linkages of marine ecosystems. In conservation, women have frequently advocated for the common good, raising their voice for the common good of conservation. From studies on sustainability, it is clear that they are regarded as major actors of sustainable development due to their inclusiveness and collaborative roles. In maritime industry, 
women enlarge the talent pool for innovation and smart growth (not for the sake of equity by itself). Therefore, in conclusion, ocean governance needs necessarily to pass through acknowledging women's role and contribution for its effectiveness.

Possibilities for promoting the involvement of woman in ocean governance and policy-making are manifold, as for example programs such as the "Initiative for Women Marine Scientists" ${ }^{\text {of }}$ UNESCO-IOC. However, as far back as the year 2000, studying gender and sustainable development in the Pacific, Fairbairn-Dunlop [54] found that women's educational achievements do not translate into equal participation in the economic, social or political spheres suggesting that "the lack of participation of women in national decision-making means that the concerns women see as important (...) may not be discussed at their national planning forums” (p. 71). Most urgently, it is necessary to reduce the structural, and systemically embedded hurdles that continue to assure gendered decision-taking with regard to the ocean. This viewpoint does not only advocate for gender equality, but for the achieving of sustainability through ocean governance. Women and gender studies should not be confined in a separated category from ocean governance. By separating and labelling, we confine women's contribution from the real decision making arenas. It is time to remove barriers for women to access to government and governance arenas for the sake of ocean sustainability.

To circle back, just as for the clownfish and the anglerfish, the marine environment provides a backdrop of gender-blurring opportunities. Roles of women in marine policy, governance and science are clearly evolving and the potential for women's voices to contribute in these areas, particularly for reaching sustainability goals, is great. It is high time to seize the moment for acknowledgement, encouragement and support of such achievements.

\section{Acknowledgments}

This research was conducted in the framework of COST action on "Ocean Governance for Sustainability - challenges, options and the role of science", CA15217, within the Gender/Parenthood/Early Career Internal group activities. We would like to thank COST for the funding that made the cooperation amongst the authors, and thus this article, possible.

\footnotetext{
${ }^{4}$ Within the program "Women marine scientists share their stories", IOC-UNESCO aims to encourage young women to pursue careers in science and in particular, science related to the ocean, disseminating the contribution of women who have dedicated their lives to marine sciences and to the protection of the marine environment, in order to promote gender equality, source: http:/www.unesco.org/new/en/natural-sciences/ioc-oceans/focus-areas/genderequality/women-marine-scientists-share-their-stories/.
} 


\section{References}

[1] S. R. Palumbi, A. R. Palumbi, The Extreme Life of the Sea. Princeton University, Princeton, New Jersey, 2014.

[2] M. R. Keen, A. M. Schwarz, L. Wini-Simeon, Towards defining the Blue Economy: Practical lessons from pacific ocean governance. Mar. Policy, 2017, doi: 10.1016/j.marpol.2017.03.002.

[3] R. Lubbers, Preface, in: E.M. Borgese, The ocean circle, United Nations University Press, Tokyo, Japan, 1998.

[4] United Nations, Sustainable development goals 17 goals to transform our world. 2017, Retrieved from http://www.un.org/sustainabledevelopment/sustainable-development-goals/ [5] C. Folke, T. Hahn, P. Olsson, J. Norberg, Adaptive governance of social-ecological systems. Annu. Rev. Environ. Resour. 2005 (30) 441-473.

[6] P. Olsson, L. H. Gunderson, S. R. Carpenter, P. Ryan, L. Lebel, C. Folke, C. S. Holling, Shooting the rapids: navigating transitions to adaptive governance of social-ecological systems, Ecology and society, 2006 11(1): 18.

[7] O. R. Young, On environmental governance: Sustainability, efficiency, and equity. Routledge, London, 2013.

[8] A.M. Jaggar, Feminist ethics. In: L.C. Becker \& C. B. Becker, The Encyclopedia of Ethics, Garland Publishing, New York, 1992.

[9] S. MacGregor, Gender and the Environment: an introduction. Routledge Handbook on Gender and the Environment. Routledge, Oxford, 2017.

[10] UNESCO, UNESCO Science Report: towards 2030. Paris, UNESCO, 2015, available at http://unesdoc.unesco.org/images/0023/002354/235406e.pdf (accessed at 3/11/2017).

[11] UNESCO-IOC, Global Ocean Science Report, Paris: UNESCO IOC, 2017, available at https://en.unesco.org/gosr (accessed at 3/11/2017).

[12] J. Mack, The Sea: A Cultural History. Reaktion Books, London, 2011.

[13] S. Laderman, Empire in Waves: A Political History of Surfing, University of California Press, Berkeley, 2014.

[14] R. Astuti, People of the Sea: Identity and descent among the Vezo of Madagascar. Cambridge University Press, Melbourne, 1995.

[15] K. Schneider, Saltwater Sociality: A Melanesian Island Ethnography, Berghahn Books. New York and Oxford, 2012. 
[16] E. Probyn, Women following fish in a more-than-human world, Gender Place Cult. 21 (2014) 589-603.

[17] D. Pauly, On the Sex of Fish and the Gender of Scientists: Collected Essays in Fisheries Science, Chapman \& Hall, London, 1994.

[18] M. Hauzer, P. Dearden, G. Murray, The fisherwomen of Ngazidja island, Comoros: Fisheries livelihoods, impacts, and implications for management, Fish. Res. 140 (2013) 28-35.

[19] S. Harper, D. Zeller, M. Hauzer, D. Pauly, U. R. Sumaila, Women and fisheries: Contribution to food security and local economies, Mar. Policy 39 (2013) 56-63.

[20] D. Kleiber, L. M. Harris, A. C. Vincent, Gender and small-scale fisheries: a case for counting women and beyond. Fish Fish. 16(4) (2015) 547-562

[21] J. S. A. Mina, D. A. R. Fernández, A. A. Ibarra, N. Georgantzis, Economic behavior of fishers under climate-related uncertainty: Results from field experiments in Mexico and Colombia. Fish. Res.183 (2016) 304-317.

[22] M. Fonseca, F. Alves, M. C. Macedo, U. M. Azeiteiro, The Women Role of the Marine Artisanal Fishery: A Study of a Fishery Community of the City of Rio das Ostras, RJ, Brazil. Revista de Gestão Costeira Integrada, 16 (2016) 231-241.

[23] E. Kim, Conceptual practice of 'rural wellbeing' in Uzbekistan: Contradictions and implications for gender equality, Rural Society 23(3) (2014) 243-256.

[24] M. Zhao, M. Tyzack, R. Anderson, E. Onoakpovike, Women as visible and invisible workers in fisheries: a case study of Northern England, Mar. Policy 37 (2013) 69-76, http://dx.doi.org/10.1016/j.marpol.2012.04.013.

[25] S. Calhoun, F. Conway, S. Russell, Acknowledging the voice of women: implications for fisheries management and policy, Mar. Policy 74 (2016) 292-299.

[26] W. Souder, On a Farther Shore, The Life and Legacy of Rachel Carson. Random House, New York, 2012.

[27] J. Saeger, Rachel Carson was right - then and now, In: S. MacGregor (Ed), Routledge Handbook on Gender and the Environment. Routledge, Oxford, 2017.

[28] R. Rosenblatt, 1998, "Sylvia Earle: Call of the Sea" Time. Retrieved December 16, 2011 http://content.time.com/time/magazine/article/0,9171,989255,00.html.

[29] D. K. Smith, Women exploring the ocean: womenoceanographers.org fifteen years later. Oceanography 27(4) (2014) 29, http://dx.doi.org/10.5670/oceanog.2014.111.

[30] R. E. Brennan, M. E. Portman, Situating Arab-Israeli artisanal fishermen's perceptions of marine litter in a socio-institutional and socio-cultural context, Mar. Pollut. Bull. 115(1-2) (2017) 240-251. 
[31] H. Tallis, J. Lubchenco, A call for inclusive conservation, Nature 515(7525) (2014) 27.

[32] United Nations, "Transforming our world: the 2030 Agenda for Sustainable Development 70/1", Resolution adopted by the General Assembly on 25 September 2015, 21 October 2015 $\mathrm{A} / \mathrm{RES} / 70 / 1$.

[33] R. Madrigal-Ballestero, A. Schlüter, M. C. Lopez, What makes them follow the rules? Empirical evidence from turtle egg harvesters in Costa Rica, Mar. Policy 37(2013) 270-277. [34] H. Eriksson, J. Albert, S. Albert, R. Warren, K. Pakoa, N. Andrew, The role of fish and fisheries in recovering from natural hazards: Lessons learned from Vanuatu, Environ. Sci. Policy 76 (2017) 50-58.

[35] D. Revollo-Fernández, A. Aguilar-Ibarra, F. Micheli, A. Sáenz-Arroyo, Exploring the role of gender in common-pool resource extraction: evidence from laboratory and field experiments in fisheries, Appl. Econ. Lett. 23(13) (2016) 912-920.

[36] V. Ram-Bidesi, Recognizing the role of women in supporting marine stewardship in the Pacific Islands, Mar. Policy 59 (2015) 1-8.

[37] S. Arora-Jonsson, Virtue and vulnerability: Discourses on women, gender and climate change, Global. Environ. Chang. 21 (2011) 744-51, https://doi.org/10.1016/j.gloenvcha.2011.01.005.

[38] L. Westberg, S. Powell, Participate for Women's Sake? A Gender Analysis of a Swedish Collaborative Environmental Management Project, Soc. Natur. Resour. 28(11) (2015) 1233-1248, http://dx.doi.org/10.1080/08941920.2015.1014594.

[39] M. Gustavsson, L. Lindström, N. S. Jiddawi, M. De La Torre-Castro, Procedural and distributive justice in a community-based managed Marine Protected Area in Zanzibar, Tanzania, Mar. Policy 46 (2014) 91-100.

[40] M. de la Torre-Castro, S. Fröcklin, S. Börjesson, J. Okupnik, N. S. Jiddawi, Gender analysis for better coastal management-Increasing our understanding of social-ecological seascapes, Mar. Policy 83 (2017) 62-74.

[41] M. Baker-Médard, Gendering Marine Conservation: The Politics of Marine Protected Areas and Fisheries Access, Soc. Natur. Resour. 30(6) (2017) 723-737.

[42] C. Brugere, Mainstreaming gender in transboundary natural resources projects-the experience of the Bay of Bengal Large Marine Ecosystem (BOBLME) project, Environmental Development 11 (2014) 84-97.

[43] K. Khodijah, Sustainable Livelihoods of Fishermen Households Headed by Women (Case Study in Riau Islands Province of Indonesia), Asian Social Science 10(9) (2014) 187.

[44] A. M. Hanson, Women's environmental health activism around waste and plastic pollution in the coastal wetlands of Yucatán. Gender \& Development 25(2) (2017) 221-234. 
[45] M. Kitada, E. Williams, L. L. Froholdt, Conclusions, In: M. Kitada, E. Williams, L. L. Froholdt (eds.), Maritime Women: Global Leadership, WMU Studies in Maritime Affairs 3, Springer-Verlag Berlin Heidelberg, 2015, 287-294.

[46] P. Tansey, Women at the Helm: 25 Years of IMO's Gender Programme, In: M. Kitada, E. Williams, L. L. Froholdt (eds.), Maritime Women: Global Leadership, WMU Studies in Maritime Affairs 3, Springer-Verlag Berlin Heidelberg, 2015, pp. 17-22.

[47] International Labour Organization (ILO) (2003) Women Seafarers: Global employment policies and practices, International Labour Office, Geneva, ISBN 92-2-113491-1, 25 Swiss francs. [48] C. B. N. Chin, Cruising in the Global Economy: Profits, Pleasure and Work at Sea, Routledge, Abingdon, 2008.

[49] International Maritime Organization (IMO), Integrated Technical Cooperation Programme, Annual Report for 2014, Technical Cooperation Committee, 65th session, TC 65/3(a), 20 April 2015.

[50] International Maritime Organization (IMO), document "World Maritime Day: A Concept of Sustainable Maritime Transportation System" (2013), available at http://www.imo.org/en/About/Events/WorldMaritimeDay/WMD2013/Documents/CONCEPT\%20 OF\%20\%20SUSTAINABLE\%20MARITIME\%20TRANSPORT\%20SYSTEM.pdf (accessed at 01/09/2017)

[51] L. L. Froholdt, E. Williams, M. Kitada, Introduction, In: M. Kitada, E. Williams, L. L. Froholdt (eds.), Maritime Women: Global Leadership, WMU Studies in Maritime Affairs 3, Springer-Verlag Berlin Heidelberg, 2015, pp. 1-16.

[52] B. Mackenzie, The "leaky pipeline": Examining and addressing the loss of women at consecutive career stages in marine engineering, science and technology, In: M. Kitada, E. Williams, L. L. Froholdt (eds.), Maritime Women: Global Leadership, WMU Studies in Maritime Affairs 3, Springer-Verlag Berlin Heidelberg, 2015, pp. 69-82.

[53] International Maritime Organization (IMO), Technical Co-Operation Committee, Integration of women in the maritime sector, Report on 2012, 63rd session, Agenda item 8, TC 63/8, 26 April 2013.

[54] P. Fairbairn-Dunlop, Gender, culture and sustainable development - the Pacific Way, in A. Hooper, Culture and sustainable development in the Pacific, Australian National University Press and Asia Pacific Press, Camberra, 2000. 